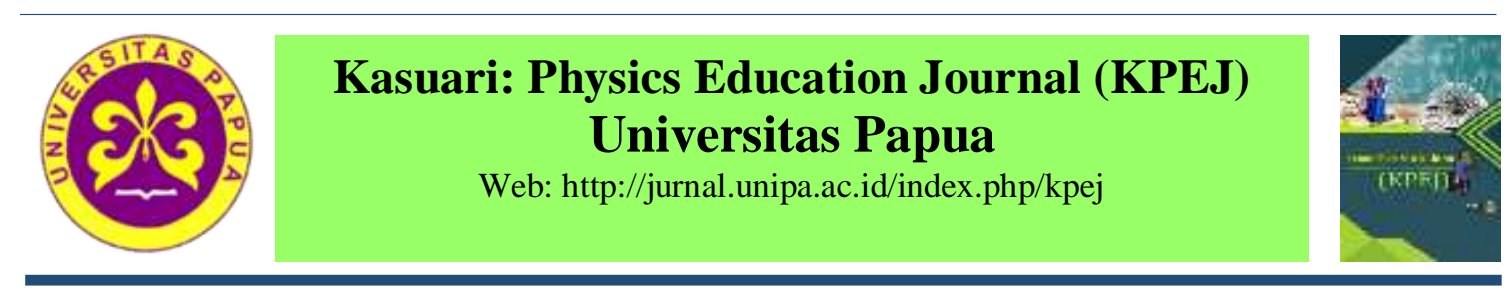

\title{
Project Based Learning Model Based on Simple Teaching Tools and Critical Thinking Skills
}

\author{
Sri Wahyu Widyaningsih \& Irfan Yusuf* \\ Program Studi Pendidikan Fisika Fakultas Keguruan dan Ilmu Pendidikan Universitas Papua \\ *Corresponding author: i.yusuf@unipa.ac.id
}

\begin{abstract}
This study aims to determine the application of PjBL model based on simple props and critical thinking skills of students in the School Laboratory course. This research uses research type PreExperimental Design with sample of all students of semester II which programmed Laboratory School on even semester 2016/2017 in Program Studi Pendidikan Fisika Fakultas Keguruan dan Ilmu Pendidikan Universitas Papua. The results showed that the props designed by students $74.0 \% \pm S D 4.2$ or are in a good category. Assessment of practical worksheet covers the aspect of format, content, language/writing, and benefits/functions obtained $80.3 \% \pm S D 7.4$ or are in the very good category. Critical thinking skills of the students during the learning that is $66.7 \% \pm S D 4.9$ or are in a good category. Therefore the application of PjBL learning based on simple props can be used to develop critical thinking skills.
\end{abstract}

Keywords: simple aids, critical thinking skills, PjBL

\section{Model Project Based Learning Berbasis Alat Peraga Sederhana dan Keterampilan Berfikir Kritis}

\begin{abstract}
Abstrak: Penelitian ini bertujuan untuk mengetahui penerapan model PjBL berbasis alat peraga sederhana dan keterampilan berpikir kritis mahasiswa dalam mata kuliah Laboratorium Sekolah. Penelitian ini menggunakan tipe penelitian Pre-Experimental Design dengan sampel seluruh mahasiswa semester II yang memprogramkan Laboratorium Sekolah pada Semester Genap 2016/2017 di Program Studi Pendidikan Fisika Fakultas Keguruan dan Ilmu Pendidikan Universitas Papua. Hasil penelitian menunjukkan bahwa alat peraga yang dirancang oleh mahasiswa diperoleh nilai 74,0\% \pm SD 4.2 atau berada dalam kategori yang baik. Penilaian hasil kerja mahasiswa berdasarkan lembar kerja mahasiswa mencakup aspek format, konten, bahasa/tulisan, dan manfaat/fungsi yaitu 80,3\% \pm SD 7,4 atau berada dalam kategori sangat baik. Kemampuan berpikir kritis mahasiswa selama pembelajaran yaitu $66,7 \% \pm$ SD 4,9 atau berada dalam kategori baik. Oleh karena itu penerapan pembelajaran PjBL berbasis alat peraga sederhana dapat digunakan untuk mengembangkan keterampilan berpikir kritis.
\end{abstract}

Kata kunci: alat peraga sederhana, keterampilan berpikir kritis, PjBL

\section{PENDAHULUAN}

Undang-Undang Nomor 20 Tahun 2003 tentang Sistem Pendidikan Nasional, Pasal 1 No. 1 menyatakan bahwa pendidikan adalah usaha sadar dan terencana untuk mewujudkan suasana belajar dan proses pembelajaran agar peserta didik secara aktif mengembangkan potensi dirinya untuk memiliki kekuatan spiritual keagamaan, pengendalian diri, kepribadian, kecerdasan, akhlak mulia, serta keterampilan yang diperlukan dirinya, masyarakat, bangsa dan negara. Salah satu keterampilan yang diperlukan mahasiswa terhadap dirinya, masyarakat, bangsa dan negara adalah keterampilan berpikir tingkat tinggi. 
Kemampuan berpikir tingkat tinggi perlu dilatihkan kepada peserta didik agar mampu menyelesaikan berbagai persoalan yang dihadapi (Tanujaya, dkk., 2017). Salah satu kemampuan berpikir tingkat tinggi yaitu kemampuan berpikir kritis. Kemampuan berpikir kritis adalah satu dari bagian penting dalam segala aspek kehidupan seseorang (Cahill \& Schulman, 2012). Dalam kehidupan sehari-hari, tentu tidak pernah lepas dari masalah yang menuntut untuk berpikir kritis. Berpikir kritis digunakan dalam berbagai situasi dan kesempatan dalam upaya memecahkan persoalan kehidupan dan dalam membuat keputusan serta membiasakan untuk bersikap ilmiah (Buntod, dkk., 2010). Oleh karena itu menjadi penting pula seseorang untuk belajar tentang bagaimana berpikir kritis, karena seseorang tidak serta merta mampu berpikir kritis tanpa melalui proses belajar. Berpikir kritis adalah sebuah keterampilan yang didapatkan melalui proses, bukan merupakan sifat yang diwariskan orang tua kepada anaknya untuk itu perlu adanya upaya untuk mengajarkan tentang bagaimana berpikir kritis kepada mahasiswa melalui materi perkuliahan yang dipelajari.

Mata kuliah Laboratorium Sekolah adalah salah satu mata kuliah yang mempelajari tentang pembuktian fenomena yang terjadi di alam melalui praktikum. Hal ini jelas mengindikasikan bahwa banyak bagian-bagian dari mata kuliah ini yang dapat digunakan untuk menumbuhkan keterampilan berpikir kritis, karena di dalamnya terdapat materimateri yang menuntut mahasiswa untuk menggali lebih dalam keterampilan berpikirnya dengan pemberian pengalaman belajar secara langsung melalui kerja ilmiah. Ennis (1996) menyebutkan secara umum 6 indikator berpikir kritis yang disingkat dengan FRISCO, yaitu: Focus (fokus), Reason (alasan), Inference (inferensi), Situation (situasi), Clarity (kejelasan) dan Overview (tinjauan ulang). Masing-masing indikator diuraikan pada Tabel 1.

Tabel 1. Indikator berpikir kritis

\begin{tabular}{|c|c|c|}
\hline No & Keterampilan Berpikir Kritis & Indikator \\
\hline 1 & Mengenal masalah (focus) & $\begin{array}{l}\text { - Merumuskan masalah dalam bentuk } \\
\text { pertanyaan }\end{array}$ \\
\hline 2 & Memberikan argument (reason) & 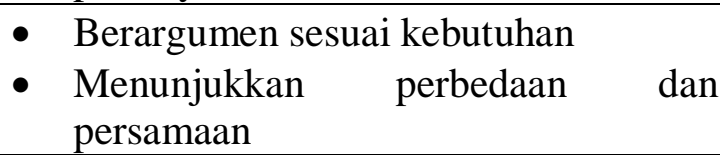 \\
\hline 3 & Memberikan asumsi (inferensi) & - $\quad$ Menyusun hipotesis \\
\hline 4 & $\begin{array}{l}\text { Menguji hipotesis dengan situasi- } \\
\text { situasi (situation) }\end{array}$ & $\begin{array}{l}\text { - Menyusus rancangan penyelesaian } \\
\text { masalah } \\
\text { - Menganalisis data }\end{array}$ \\
\hline 5 & $\begin{array}{l}\text { Menyimpulkan untuk memeperjelas } \\
\text { solusi masalah (clarity) }\end{array}$ & - Menarik kesimpulan \\
\hline 6 & $\begin{array}{l}\text { Memutuskan dan melaksanakan } \\
\text { (overview) }\end{array}$ & $\begin{array}{l}\text { - Memilih kemungkinan yang akan } \\
\text { dilaksanakan }\end{array}$ \\
\hline
\end{tabular}

Salah satu solusi yang dapat ditempuh untuk menumbuhkan keterampilan berpikir kritis tersebut yaitu dengan menerapkan model Project Based Learning (PjBL) dalam pembelajaran. Hal ini sesuai dengan Permendikbud No. 65 tahun 2013 tentang Standar Proses yaitu untuk mendorong kemampuan peserta didik untuk menghasilkan karya kontekstual, baik individual maupun kelompok maka sangat disarankan menggunakan pendekatan pembelajaran yang menghasilkan karya/proyek berbasis pemecahan masalah (Project Based Learning). 
Pelaksanaan praktikum dalam pembelajaran sebagai pendukung pemecahan masalah pada PjBL sangat diperlukan. Tapi masalah kurangnya alat dan bahan masih menjadi hambatan di sebagian besar sekolah di Kabupaten Manokwari Papua Barat yang diamati pada saat mahasiswa melakukan Praktek Latihan Profesi (PLP). Mahasiswa sebagai calon guru perlu memiliki kreatifitas yang tinggi. Salah satu solusi yang dapat dilakukan untuk mengatasi keterbatasan itu adalah merancang alat peraga sederhana yang diperoleh dari bahan yang ada di sekitar dan dengan harga yang terjangkau. Sesuai dengan pernyataan Widyaningsih \& Yusuf (2015) solusi alternatif untuk mengatasi masalah tersebut adalah dengan membuat sendiri alat peraga sederhana. Penggunakan alat peraga memberikan kesan bahwa fisika itu sebenarnya ilmu yang menyenangkan sehingga pemahamannya tentang konsep-konsep fisika yang abstrak menjadi lebih nyata (Widyaningsih, 2011). Tujuan yang diharapkan dalam penelitian ini yaitu mengetahui penerapan model PjBL berbasis alat peraga sederhana pada mata kuliah Laboratorium Sekolah serta keterampilan berfikir kritis mahasiswa selama proses pembelajaran.

\section{METODE PENELITIAN}

Penelitian ini menggunakan jenis penelitian Pre-Eksperimental Design (nondesign) jenis One-Shot Case Study (Sugiyono, 2010:110). Sampel dalam penelian ini yaitu seluruh mahasiswa semester II yang memprogramkan Laboratorium Sekolah pada Semester Genap 2016/2017 di Program Studi Pendidikan Fisika Fakultas Keguruan dan Ilmu Pendidikan Universitas Papua. Instrumen dalam penelitian ini yaitu lembar penilaian alat peraga sederhana dan LKPD yang dirancang oleh mahasiswa serta lembar observasi keterampilan berfikir kritis mahasiswa yang dinilai selama proses pembelajaran $\mathrm{PjBL}$ menggunakan alat peraga sederhana yang dirancang. Data yang diperoleh dari instrumen penilaian alat peraga sederhana dan LKPD serta observasi keterampilan berfikir kritis mahasiswa dilakukan teknik analisis pengkodean penilaian dan analisis dekriptif kuantitatif.

Penilaian alat peraga, LKPD, dan keterampilan berfikir kritis mahasiswa selam proses pembelajaran dilakukan dengan memberikan skor berdasarkan ketentuan yang dapat diliha pada Tabel 2.

Tabel 2. Pengkodean Tanggapan Penilaian

\begin{tabular}{|c|c|c|}
\hline Katagori & Skor Setiap Pernyataan Positif & Skor Setiap Pernyataan Negatif \\
\hline Sangat Setuju & 4 & 1 \\
\hline Setuju & 3 & 2 \\
\hline Kurang Setuju & 2 & 3 \\
\hline Tidak Setuju & 1 & 4 \\
\hline
\end{tabular}

Sumber: Riduwan (2011)

Menghitung persentase penilaian untuk setiap pernyataan sesuai dengan kriteria penilaian menggunakan persamaan (1).

$$
\text { Persentase }=\frac{Y}{X} 100 \%
$$

Dimana:

$\mathrm{Y}=$ skor hasil penilaian observer

$\mathrm{X}=$ skor maksimal

Hasil perhitungan persentase persentase penilaian kemudian diinterpretasi menggunakan Tabel 3. 
Tabel 3. Kriteria interpretasi skor

\begin{tabular}{|c|c|}
\hline Persentase (\%) & Kriteria \\
\hline $0-25$ & Sangat Kurang \\
\hline $26-50$ & Kurang \\
\hline $51-75$ & Baik \\
\hline $76-100$ & Sangat Baik \\
\hline
\end{tabular}

Sumber: Riduwan (2011)

\section{HASIL DAN PEMBAHASAN}

Pada hasil dan pembahasan disajikan dengan tabel atau grafik, untuk memperjelas hasil secara verbal. Hasil dan pembahasan merupakan bagian terpenting dari keseluruhan isi artikel ilmiah. Tujuan pembahasan adalah menjawab masalah penelitian, menafsirkan temuan-temuan, mengintegrasikan temuan dari penelitian ke dalam kumpulan pengetahuan yang telah ada dan menyusun teori baru atau memodifikasi teori yang sudah ada. Bagian pembahasan memaparkan hasil penemuan secara logis dan sangat disarankan mengaitkan dengan sumber rujukan yang relevan. Alat peraga sederhana yang dirancang oleh setiap kelompok mahasiswa meliputi percobaan fluida, optik, mekanika, bandul matematis, termometer sederhana, kalorimeter, rangkaian listrik seri paralel, listrik statis, dan percobaan radiasi benda hitam. Salah satu alat peraga yang dirancang oleh mahasiswa dapat dilihat pada Gambar 1.

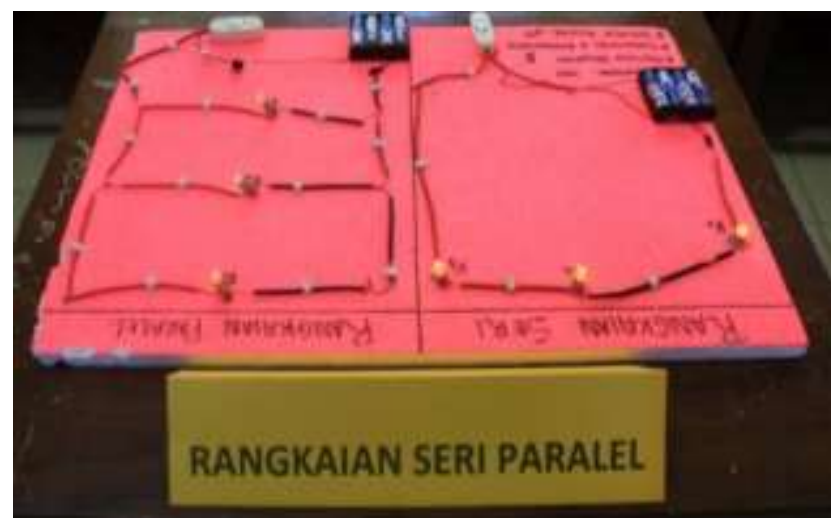

Gambar 1. Alat peraga sederhana

Alat peraga yang dirancang oleh mahasiswa dinilai oleh peneliti dengan mengisi lembar penilaian alat peraga sederhana yang telah dibuat. Penilaian dilakukan setelah seluruh mahasiswa mengumpulkan alat peraga. Berdasarkan penilaian alat peraga yang dirancang melalui penugasan projek Tabel 4 diperoleh hasil keseluruhan 74,0\% \pm SD 4,2 atau kategori baik. Penilaian pada setiap aspek dan kriteria alat peraga yang dinilai berada pada kategori baik dan sangat baik. Penilaian alat peraga yang dirancang oleh setiap kelompok juga diperoleh penilaian baik dan sangat baik, tidak ada kriteria atau kelompok mahasiswa yang memperoleh penilaian pada kategori kurang. Hal tersebut menunjukkan bahwa melalui pembelajaran PjBL yang menuntut mahasiswa untuk menyelesaikan tugas projek berupa alat peraga sederhana yang memanfaatkan bahanbahan lokal dengan biaya yang relatif murah. Sejalan dengan pernyataan Saputri \& Dewi (2014) alat peraga sederhana dapat dibuat sendiri sesuai dengan konsep materi yang akan diajarkan dengan memanfaatkan bahan bekas yang berada di lingkungan sekitar, tanpa harus mengeluarkan banyak biaya. 
Tabel 4. Penilaian alat peraga sederhana yang dirancang mahasiswa selama pembelajaran PjBL

\begin{tabular}{|c|c|c|c|c|c|}
\hline No & $\begin{array}{c}\text { Aspek } \\
\text { Penilaian }\end{array}$ & Kriteria & \multicolumn{2}{|c|}{ Persetase } & Kategori \\
\hline \multirow[t]{3}{*}{1} & \multirow[t]{3}{*}{ Materi } & Kebenaran konten & 72,2 & \multirow{3}{*}{74,1} & \multirow{3}{*}{ Baik } \\
\hline & & $\begin{array}{l}\text { Kesesuaian materi dalam alat peraga } \\
\text { dengan Kurikulum KTSP atau K } 13\end{array}$ & 75,0 & & \\
\hline & & $\begin{array}{l}\text { Dapat mengembangkan aktivitas berpikir } \\
\text { kritis peserta didik }\end{array}$ & 75,0 & & \\
\hline \multirow[t]{5}{*}{2} & \multirow[t]{5}{*}{ Penyajian } & Keberfungsian alat peraga & 75,0 & \multirow{5}{*}{71,7} & \multirow{5}{*}{ Baik } \\
\hline & & Daya tahan alat peraga sederhana & 63,9 & & \\
\hline & & Memperhatikan keselamatan kerja & 72,2 & & \\
\hline & & $\begin{array}{l}\text { Memperhatikan kemampuan/gaya belajar } \\
\text { peserta didik yang berbeda }\end{array}$ & 75,0 & & \\
\hline & & Memberikan pengalaman lebih nyata & 72,2 & & \\
\hline \multirow[t]{3}{*}{3} & \multirow{3}{*}{$\begin{array}{l}\text { Daya } \\
\text { Tarik }\end{array}$} & Desain alat peraga & 77,8 & \multirow{3}{*}{77,8} & \multirow{3}{*}{$\begin{array}{l}\text { Sangat } \\
\text { Baik }\end{array}$} \\
\hline & & $\begin{array}{l}\text { Kemudahan dalam penggunaan alat } \\
\text { peraga (ramah pengguna) }\end{array}$ & 75,0 & & \\
\hline & & $\begin{array}{l}\text { Membangkitkan motivasi/minat/rasa } \\
\text { ingin tahu peserta didik }\end{array}$ & 80,6 & & \\
\hline \multicolumn{3}{|c|}{ Persentase } & $\mathbf{7 4 , 0}$ & & \\
\hline \multicolumn{3}{|c|}{ SD } & 4,2 & & \\
\hline \multicolumn{3}{|c|}{ Kategori } & Baik & & \\
\hline
\end{tabular}

Penggunaan alat peraga sederhana yang dirancang oleh mahasiswa menjadi salah satu alternatif mengatasi keterbatasan alat dan bahan praktikum di laboratorium sekolah. Pada umumnya sekolah-sekolah di Kab. Manokwari Papua Barat tidak tersedia perangkat percobaan untuk memenuhi kompetensi yang diharapkan pada tujuan pembelajaran terutama pada mata pelajaran sains seperti IPA. Penggunaan alat peraga sederhana merupakan alternatif yang dapat dilakukan oleh guru sehingga mahasiswa sebagai calon guru juga harus dibekali keterampilan merancang berbagai media pembalajaran salah satunya adalah alat peraga sederhana. Agus (2007) yang menyatakan bahwa penggunaan alat peraga dalam kegiatan pembelajaran sangat menentukan keberhasilan pencapaian tujuan pembelajaran yang dikehendaki.

Selain merancang alat peraga sederhana, mahasiswa juga merancang LKPD untuk menuntun peserta didik melakukan percobaan menggunakan alat peraga yang dirancang. Tampilan LKPD yang dirancang dapat dilihat pada Gambar 2.

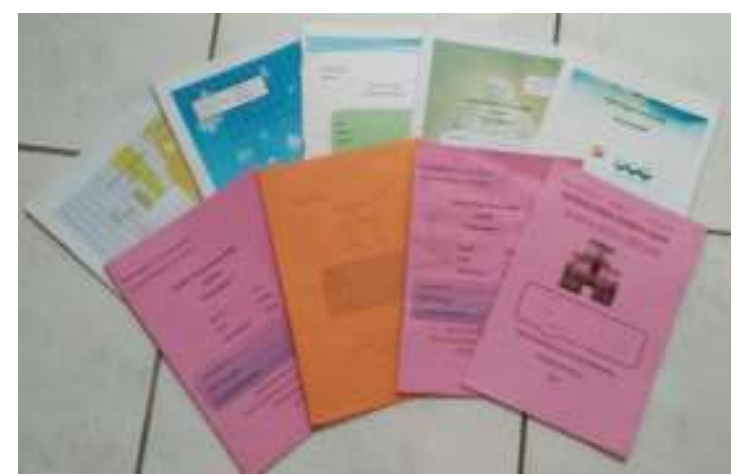

Gambar 2. LKPD alat peraga sederhana hasil rancangan 
Penilaian LKPD alat peraga sederhana yang dirancang mahasiswa selama pembelajaran PjBL dapat dilihat pada Tabel 5.

Tabel 5. Penilaian LKPD alat peraga sederhana

\begin{tabular}{|c|c|c|c|c|c|}
\hline No. & Aspek & Kriteria Penilaian & Pers & ntase & Kategori \\
\hline \multirow{6}{*}{1.} & \multirow{6}{*}{ Format } & $\begin{array}{lr}\text { Kesesuaian format LKPD untuk } \\
\text { mengembangkan } & \text { Keterampilan } \\
\text { Bereksperimen Peserta Didik }\end{array}$ & 97,2 & \multirow{6}{*}{84,3} & \multirow{6}{*}{$\begin{array}{l}\text { Sangat } \\
\text { Baik }\end{array}$} \\
\hline & & Terdapat Penomoran & 94,4 & & \\
\hline & & Kemenarikan & 83,3 & & \\
\hline & & Kejelasan pembagian unit kegiatan & 75,0 & & \\
\hline & & Jenis dan ukuran huruf & 77,8 & & \\
\hline & & Pengaturan ruang (tata letak) & 77,8 & & \\
\hline \multirow{7}{*}{2.} & \multirow{7}{*}{ Isi } & $\begin{array}{l}\text { Kesesuaian dengan kurikulum yang } \\
\text { berlaku (KTSP dan K13). }\end{array}$ & 83,3 & \multirow{7}{*}{77,8} & \multirow{7}{*}{$\begin{array}{l}\text { Sangat } \\
\text { Baik }\end{array}$} \\
\hline & & Kebenaran konsep & 77,8 & & \\
\hline & & Kejelasan prosedur kegiatan & 69,4 & & \\
\hline & & $\begin{array}{l}\text { Penyajian unit kegiatan dimulai dari } \\
\text { yang sederhana beranjak ke yang } \\
\text { kompleks atau dari konkrit ke abstrak. }\end{array}$ & 75,0 & & \\
\hline & & Mengembangkan keterampilan. & 75,0 & & \\
\hline & & Mendorong minat untuk bekerja & 86,1 & & \\
\hline & & $\begin{array}{l}\text { Kesesuaian dengan media alat peraga } \\
\text { sederhana yang digunakan }\end{array}$ & 77,8 & & \\
\hline \multirow{4}{*}{3} & \multirow{4}{*}{$\begin{array}{l}\text { Bahasa/ } \\
\text { Tulisan }\end{array}$} & $\begin{array}{l}\text { Menggunakan bahasa yang } \\
\text { komunikatif dan struktur kalimat yang } \\
\text { sederhana, sesuai dengan taraf berfikir } \\
\text { dan kemampuan peserta didik. }\end{array}$ & 75,0 & \multirow{4}{*}{75,0} & \multirow{4}{*}{ Baik } \\
\hline & & $\begin{array}{l}\text { Menggunakan bahasa Indonesia yang } \\
\text { baik dan benar }\end{array}$ & 75,0 & & \\
\hline & & $\begin{array}{l}\text { Menggunakan istilah-istilah secara } \\
\text { tepat dan mudah dipahami oleh peserta } \\
\text { didik }\end{array}$ & 75,0 & & \\
\hline & & $\begin{array}{l}\text { Menggunakan arahan dan petunjuk } \\
\text { yang jelas, sehingga tidak } \\
\text { menimbulkan penafsiran ganda. }\end{array}$ & 75,0 & & \\
\hline \multirow[b]{2}{*}{4.} & \multirow{2}{*}{$\begin{array}{l}\text { Manfaat/ } \\
\text { Kegunaan }\end{array}$} & $\begin{array}{l}\text { Dapat digunakan sebagai pelengkap } \\
\text { media alat peraga sederhana dalam } \\
\text { pembelajaran. }\end{array}$ & 86,1 & \multirow[b]{2}{*}{87,5} & \multirow{2}{*}{$\begin{array}{l}\text { Sangat } \\
\text { Baik }\end{array}$} \\
\hline & & $\begin{array}{l}\text { Dapat merubah } \\
\text { pembelajaran yang terpusat kepiasaan } \\
\text { guru menjadi terpusat kepada peserta } \\
\text { didik. }\end{array}$ & 88,9 & & \\
\hline \multicolumn{3}{|r|}{$\%$} & 80,3 & & \\
\hline \multicolumn{3}{|r|}{ SD } & 7,4 & & \\
\hline \multicolumn{3}{|r|}{ Kategori } & \multicolumn{3}{|c|}{ Sangat Baik } \\
\hline
\end{tabular}


LKPD yang dirancang oleh mahasiswa sebagai bagian dari alat peraga sederhana secara keseluruhan diperoleh hasil $80 \% \pm$ SD 7,4 atau kategori sangat baik sebagaimana pada Tabel 5. LKPD yang dirancang dituntut berbagai keterampilan bereksperimen peserta didik, sehingga mahasiswa ditugaskan merancang bukan hanya sekedar membuat alat peraga sederhana berupa demontrasi tetapi peserta didik juga dituntut dapat melakukan analisis berbagai besaran fisika dan terlibat secara langsung dalam melakukan praktikum. Menurut Lindawati, dkk, 2013 bahwa pembelajaran sebaiknya memberikan pengalaman langsung dan mampu memperkenalkan peserta didik dengan kegiatan kreatif seperti pembuatan alat-alat sederhana sehingga peserta didik dapat terampil dalam menjawab berbagai masalah dalam Fisika. Penggunaan model pembelajaran PjBL dalam proses pembelajaran dapat meningkatkan kreativitas serta meningkatkan hasil belajar peserta didik. Peseta didik yang diberikan pengetahuan baru, ikut dilibatkan dalam kegiatan kreatif akan senang terhadap pelajaran tersebut yang berakibat pada peningkatan kreativitas dan hasil belajar peserta didik. Hikmah (2016) menyatakan bahwa penggunaan LKPD mampu melatih keterampilan berfikir kritis. Lebih kanjut Khanasta, dkk (2016) menyatakan bahwa LKPD yang memuat indikator-indikator keterampilan berfikir kritis mampu melatih mahasiswa untuk mengembangkan keterampilan tersebut. Hal ini didukung juga oleh Hayati, dkk (2016) yang menyatakan bahwa LKPD berbasis PjBL mampu mengembangkan keterampilan berfikir kritis.

Tabel 6. Penilaian keterampilan berpikir kritis mahasiswa yang diobservasi selama pembelajaran $\mathrm{PjBL}$

\begin{tabular}{|c|c|c|c|c|c|c|}
\hline No. & $\begin{array}{c}\text { Keterampilan } \\
\text { Berpikir }\end{array}$ & Indikator & Kegiatan Mahasiswa & \multicolumn{2}{|c|}{ Persentase } & \multirow{2}{*}{$\begin{array}{l}\text { Kategori } \\
\text { Baik }\end{array}$} \\
\hline 1 & $\begin{array}{l}\text { Mengenal } \\
\text { masalah } \\
\text { (focus) }\end{array}$ & $\begin{array}{l}\text { Merumusk } \\
\text { an } \\
\text { masalah } \\
\text { dalam } \\
\text { bentuk } \\
\text { pertanyaan }\end{array}$ & $\begin{array}{l}\text { Memberikan } \\
\text { pertanyaan sesuai } \\
\text { dengan permasalahan }\end{array}$ & 66,7 & 66,7 & \\
\hline \multirow[t]{5}{*}{2} & \multirow[t]{5}{*}{$\begin{array}{l}\text { Memberikan } \\
\text { argument } \\
\text { (reason) }\end{array}$} & \multirow[t]{3}{*}{$\begin{array}{l}\text { Berargum } \\
\text { en sesuai } \\
\text { kebutuhan }\end{array}$} & $\begin{array}{l}\text { Memberikan jawaban } \\
\text { atas permasalahan } \\
\text { yang dibahas }\end{array}$ & 58,3 & \multirow{5}{*}{65,6} & \multirow{5}{*}{ Baik } \\
\hline & & & $\begin{array}{l}\text { Memberikan saran } \\
\text { dari permasalahan } \\
\text { yang dibahas }\end{array}$ & 72,2 & & \\
\hline & & & $\begin{array}{l}\text { Memahami dan } \\
\text { menggunakan bahasa } \\
\text { yang tepat dan jelas }\end{array}$ & 69,4 & & \\
\hline & & \multirow{2}{*}{$\begin{array}{l}\text { Menunjuk } \\
\text { kan } \\
\text { perbedaan } \\
\text { dan } \\
\text { persamaan }\end{array}$} & $\begin{array}{l}\text { Dapat mengoreksi } \\
\text { argumen orang lain } \\
\text { yang tidak relevan }\end{array}$ & 58,3 & & \\
\hline & & & $\begin{array}{l}\text { Menerima setiap } \\
\text { masukan dan } \\
\text { perbedaan pendapat } \\
\text { dengan menunjukkan } \\
\text { sikap terbuka terhadap } \\
\text { kritikan }\end{array}$ & 69,4 & & \\
\hline
\end{tabular}




\begin{tabular}{|c|c|c|c|c|c|c|}
\hline No. & $\begin{array}{c}\text { Keterampilan } \\
\text { Berpikir } \\
\text { Kritis }\end{array}$ & Indikator & Kegiatan Mahasiswa & \multicolumn{2}{|c|}{ Persentase } & \multirow{2}{*}{$\begin{array}{l}\text { Kategori } \\
\text { Baik }\end{array}$} \\
\hline 3 & $\begin{array}{l}\text { Memberikan } \\
\text { asumsi } \\
\text { (inferensi) }\end{array}$ & $\begin{array}{l}\text { Menyusun } \\
\text { hipotesis }\end{array}$ & $\begin{array}{l}\text { Memberikan } \\
\text { kemungkinan solusi } \\
\text { dari permasalahan } \\
\text { secara rasional }\end{array}$ & 66,7 & 66,7 & \\
\hline \multirow[t]{3}{*}{4} & \multirow{3}{*}{$\begin{array}{l}\text { Menguji } \\
\text { hipotesis } \\
\text { dengan situasi- } \\
\text { situasi } \\
\text { (situation) }\end{array}$} & \multirow{2}{*}{$\begin{array}{l}\text { Menyusus } \\
\text { rancangan } \\
\text { penyelesai } \\
\text { an } \\
\text { masalah }\end{array}$} & $\begin{array}{l}\text { Menemukan cara-cara } \\
\text { yang dapat dipakai } \\
\text { untuk menangani } \\
\text { masalah }\end{array}$ & 66,7 & \multirow{3}{*}{69,4} & \multirow{3}{*}{ Baik } \\
\hline & & & $\begin{array}{l}\text { Menguraikan } \\
\text { penyelesaian masalah } \\
\text { secara sistematis }\end{array}$ & 72,2 & & \\
\hline & & $\begin{array}{l}\text { Menganali } \\
\text { sis data }\end{array}$ & $\begin{array}{l}\text { Menganalisis data } \\
\text { sesuai dengan } \\
\text { persamaan fisika }\end{array}$ & 69,4 & & \\
\hline 5 & $\begin{array}{l}\text { Menyimpulkan } \\
\text { untuk } \\
\text { memeperjelas } \\
\text { solusi masalah } \\
\text { (clarity) }\end{array}$ & $\begin{array}{l}\text { Menarik } \\
\text { kesimpula } \\
\mathrm{n}\end{array}$ & $\begin{array}{l}\text { Memberikan simpulan } \\
\text { secara faktual }\end{array}$ & 69,4 & 69,4 & Baik \\
\hline 6 & $\begin{array}{l}\text { Memutuskan } \\
\text { dan } \\
\text { melaksanakan } \\
\text { (overview) }\end{array}$ & $\begin{array}{l}\text { Memilih } \\
\text { kemungki } \\
\text { nan yang } \\
\text { akan } \\
\text { dilaksanak } \\
\text { an }\end{array}$ & $\begin{array}{l}\text { Mempertimbangkan } \\
\text { berbagai saran dan } \\
\text { masukan serta } \\
\text { mengungkapkan } \\
\text { argumen yang esensial }\end{array}$ & 61,1 & 61,1 & Baik \\
\hline \multicolumn{4}{|c|}{$\%$} & 66,7 & & \\
\hline \multicolumn{4}{|c|}{ SD } & 4,9 & & \\
\hline \multicolumn{4}{|c|}{ Kategori } & \multicolumn{3}{|l|}{ Baik } \\
\hline
\end{tabular}

Keterampilan berpikir kritis mahasiswa diobservasi selama kegiatan pembelajaran berlangsung yaitu pada saat mereka memaparkan hasil tugas projek yang dirancang bersama dengan kelompoknya. Hasil penilaian keterampilan berpikir kritis mahasiswa secara keseluruhan $66,7 \% \pm \mathrm{SD} 4,9$ atau kategori baik sebagaimana pada tabel 6 . Keterampilan berpikir kritis mahasiswa jika ditinjau pada setiap aspek semuanya berada pada kategori baik dan jika ditinjau berdasarkan penilaian kelompok mahasiswa diperoleh hasil baik dan sangat baik. Hal tersebut menunjukkan bahwa melalui pembelajaran PjBL berbasis alat peraga sederhana yang dirancang oleh mahasiswa dapat mengembangkan keterampilan berpikir kritis mereka. Hal ini sejalan dengan penelitian Sartika, dkk (2013) dan Luthvitasari (2013) bahwa model PjBL mampu menumbuhkan keterampilan berfikir kritis. Insyasiska, dkk (2015) menyatakan bahwa PjBL menuntut mahasiswa untuk mampu menyelesaikan proyek yang diberikan yang mampu menumbuhkan pemikiran-pemikiran kritis terhadap suatu masalah.

Penerapan PjBL dalam proses belajar mengajar menjadi sangat penting untuk meningkatkan kemampuan mahasiswa dalam berfikir secara kritis dan memberi rasa kemandirian dalam belajar. Sebagai suatu pembelajaran yang konstruktivis, PjBL menyediakan pembelajaran dalam situasi problem yang nyata bagi mahasiswa sehingga 
dapat melahirkan pengetahuan yang bersifat permanen (Rais, 2010). Selanjutnya Tiantong \& Sumalee (2013) menyatakan bahwa pembelajaran berbasis proyek adalah aplikasi teori pendidikan, penelitian dan praktek dalam konstruktivisme. Pandangan konstruktivis menganggap hal-hal nyata dalam domain pengetahuan dan dalam konteks kehidupan sehari-hari yang biasanya dilakukan, dan PjBL membimbing peserta didik untuk mengambil peran kehidupan nyata dan menerapkan alat-alat dari domain pengetahuan dalam membuat sebuah proyek. Pembelajaran berbasis proyek menyediakan konteks dimana peserta didik bergerak ke arah pemikiran sebagai ahli dalam domain pengetahuan seperti berpikir, dan dapat diaplikasikan dalam perkuliahan di pendidikan tinggi. Prinsip yang mendasari PjBL adalah bahwa tema atau masalah yang akan dipecahkan oleh mahasiswa secara bertahap mengeksplorasi masalah dari perspektif yang berbeda, menyesuaikan tujuan dan strategi mereka untuk wawasan baru yang dikumpulkan selama proyek.

\section{SIMPULAN DAN SARAN}

Berdasarkan hasil penelitian maka dapat disimpulkan bahwa pembelajaran PjBL berbasis alat peraga sederhana diperoleh hasil penugasan berupa alat peraga sederhana dan LKPD yang dirancang oleh mahasiswa yang berada pada kategori baik dan sangat baik. Alat peraga dan LKPD yang dirancang tersebut menuntut keterampilan peserta didik dalam bersperimen menggunakan alat peraga hasil rancangan mereka bukan hanya sekedar demontrasi tetapi dapat melakukan analisis berbagai besaran fisika melalui penggunaan alat peraga sederhana. Keterampilan proses sains mahasiswa selama pembelajaran yaitu $66,7 \% \pm$ SD 4,9 atau berada pada kategori baik meliputi aspek mengenal masalah (focus), memberikan argument (reason), memberikan asumsi (inferensi), menguji hipotesis dengan situasi-situasi (situation), menyimpulkan untuk memperjelas solusi masalah (clarity), serta memutuskan dan melaksanakan (overview). Oleh karena itu penerapan pembelajaran $\mathrm{PjBL}$ berbasis alat peraga sederhana dapat digunakan untuk mengembangkan keterampilan berpikir kritis.

\section{DAFTAR PUSTAKA}

Agus, M. (2007). Alat Peraga Sederhana Multifungsi untuk Pembelajaran Geografi. Jurnal Pendidikan inovatif, 2(2), 90-94.

Buntod, C. P., Suksringam, P., \& Singseevo, A. (2010). Effects of Learning Environmental Education on Science Process Skills and Critical Thinking of Mathayomsuksa 3 Students with Different Learning Achievements. Journal of Social Sciences, 6(1), 60-63.

Cahill, A. J. \& Schulman, S. B. (2012). Argumentation step-by-step: learning critical thinking through deliberate practice. Teaching Philosophy, 35(1), 41-62.

Ennis, R. H. (1996). Critical Thinking. London: Prentice Hall, Inc.

Hayati, W. I., Utaya, S., \& Astina, I. K. (2016). Efektivitas Student Worksheet Berbasis Project Based Learning Dalam Menumbuhkan Kemampuan Berpikir Kritis Siswa Pada Mata Pelajaran Geografi. Jurnal Pendidikan: Teori, Penelitian, dan Pengembangan, 1(3), 468-474.

Hikmah, N., Budiasih, E., \& Santoso, A. (2016). Pengaruh Strategi Project Based Learning (PjBL) Terhadap Kemampuan Berpikir Kritis Siswa Kelas XI IPA pada Materi Koloid, Jurnal Pendidikan: Teori, Penelitian, \& Pengembangan, 1(11), 2248-2253.

Insyasiska, D., Zubaidah, S., \& Susilo, H. (2015). Pengaruh Project Based Learning Terhadap Motivasi Belajar, Kreativitas, Kemampuan Berpikir Kritis, dan 
Kemampuan Kognitif Siswa pada Pembelajaran Biologi. Jurnal Pendidikan Biologi, 7(1), 9-21

Khanasta, I., Sinon, I. L. S., \& Widyaningsih, S. W. (2016). Penerapan Model Pembelajaran Berbasis Fenomena Menggunakan Metode Demonstrasi Terhadap Berpikir Kritis Peserta Didik Kelas XI IPA SMA Yapis Manokwari. Wahana Didaktika, 14(3), 14-27.

Lindawati, Siska, D. F., \& Arif, M. (2013). Penerapan Model Pembelajaran Project Based Learning untuk Meningkatkan Kreativitas Peserta didik MAN I Kebumen. Jurnal Radiasi, 3(1), 42-45.

Luthvitasari, N., Made D.P.N., \& Linuwih, S. (2013). Implementasi Pembelajaran Berbasis Proyek Pada Keterampilan Berpikir dan Kemahiran Generik Sains. Innovative Journal of Curriculum and Educational Technology, 2(1), 159-164.

Rais, M. (2010). Model Project Based Learning sebagai Upaya Meningkatkan Prestasi Akademik Mahasiswa. Jurnal Pendidikan dan Pengajaran, 43(3), 246-252.

Riduwan. (2011). Skala Pengukuran Variabel-Variabel Penelitian. Bandung: Alfabeta.

Saputri, V. A. C \& Dewi, N. R. (2014). Pengembangan Alat Peraga Sederhana Eye Lens Tema Mata Kelas VIII untuk Menumbuhkan Keterampilan Peserta Didik. Jurnal Pendidikan IPA Indonesia JPII, 3(2), 109-115.

Sartika, I. A. K., Sadia, I. W., \& Muderawan, I. W. (2013). Pengaruh Model Pembelajaran Berbasis Proyek Terhadap Pemahaman Konsep Kimia dan Keterampilan Berpikir Kritis. Jurnal Pendidikan dan Pembelajaran IPA Indonesia. $3(1)$.

Sugiyono. (2010). Metode Penelitian Pendidikan: Pendekatan Kuantitatif, Kualitatif, dan $R \& B$. Bandung: Alfabeta.

Tanujaya, B., Mumu, J., \& Margono, G. (2017). The relationship between higher order thinking skills and academic performance of student in Mathematics Instruction International Education Studies, 10(11), 78-85.

Tiantong, M \& Sumalee, S. (2013). The Online Project-based Learning Model Based on Student's Multiple Intelligence. International Journal of Humanities and Social Science, 3(7), 204-211.

Widyaningsih, S. W \& Yusuf, I. (2015). Penerapan Quantum Learning Berbasis Alat Peraga Sederhana untuk Meningkatkan Hasil Belajar Peserta Didik. Jurnal Ilmiah Panrita, 10(3), 680-693.

Widyaningsih, S. W. (2011). Pembentukan Karakter Bertanggung Jawab dan Rasa Ingin Tahu Melalui Penerapan Metode Quantum Learning dengan Menggunakan Media Alat Peraga Sederhana pada Pembelajaran Fisika. Seminar Nasional MIPA dan Pendidikan MIPA UNP Tahun 2011, (pp. 297-309). Padang: FMIPA. 